Helen Makogon ${ }^{1}$, Roman Suchko ${ }^{1}$, Viktor Moskalenko ${ }^{1}$, Igor Kalinin $^{1}$, Sergiy Burdin ${ }^{2}$, Viktoriia Iksarytsia ${ }^{2}$

${ }^{1}$ Military Institute of Tank Troops of National Technical University, Kharkiv, Ukraine

${ }^{2}$ State boarding school with enhanced military and physical training "Cadet Corps" Kharkiv, Ukraine

\title{
APPLICATION OF THE CORRELATION ANALYSIS MATHEMATICAL APPARATUS FOR DETERMINATION THE LEAD-ACID BATTERIES MANAGEMENT AND STATUS CONTROL MINIMUM DIAGNOSIS
}

\begin{abstract}
The subject matter of the article is the lead-acid batteries carrier and management. The goal of the study is the development of a methodology for assessing the lead-acid batteries' parameters and to provide recommendations for their long-term management and carrier in the army operation. The tasks to be solved are: on the basis of the lead-acid batteries operation experience to define a set of diagnostic parameters on which it is possible to draw a conclusion about the technical state of a battery and change of its electric, operational and design properties; to determine the correlations between the properties of the battery and make their assessment based on the established criteria; to build a diagnostic graph-model of causal relationships of a battery's parameters in the form of a correlation galaxy; to justify the lead-acid batteries carrier and management minimum diagnosis which can be carried out during their life cycle management ra status control under the lack of time. General scientific and special methods of scientific knowledge are used. The following results were obtained: The set of diagnostic parameters to assess the battery technical state was determinated. Statistical data processing using the mathematical apparatus of correlation analysis was done. The diagnostic graph model of a lead-acid battery in the form of a correlation galaxy was constructed. The lead-acid batteries carrier and management minimum diagnosis during the life cycle was determined. Conclusions. Analysis of the experience of the lead-acid batteries operation determines a set of diagnostic parameters, which can be used to draw a conclusion about the technical state of a battery and change of its electric, operational and design properties. As generalized diagnostic parameters of the battery technical state can be considered the State of Health and the State of charge. Statistical data processing using the mathematical apparatus of correlation analysis allows to determine the causal and dependencies between the battery's parameters and make their assessment based on the established criteria. Presentation of generalized results in the form of a correlation galaxy makes it possible to build a diagnostic graph-model of battery in the form of a correlation galaxy. Control of the SoC and SoH of the lead-acid battery will ensure the monitoring of the remaining charge, as well as the issuance of a warning about the need to replace the battery. A promising direction in the development of battery operation can be considered the development of batterypowered trackers - software and hardware devices capable of caring for battery care and battery management.
\end{abstract}

Keywords: lead-acid batteries; battery care and battery management; state of charge; state of health.

\section{Formulation of the problem and research tasks}

Ensuring the proper level of readiness of equipment for use largely depends on the state of the GB. During operation, the battery may have such faults as suffixation of the plates, accelerated self-discharge, short circuit, electrolyte leakage, oxidation of the pole pins, which usually leads to deterioration of its electrical characteristics. The main means of the battery maintaining in a technically sound condition during the operation of combat vehicles is timely and high-quality maintenance. Based on the list and frequency of their work are included in the first or second maintenance.

The Armed Forces has a planned and preventive system of maintenance and repair of armored weapons and military equipment (AWME) based on the mandatory performance of work on the care of AMWE and lead-acid batteries, in particular, both in the process of their use and during storage.

However, the analysis of the existing maintenance system showed its low efficiency in modern conditions and revealed a number of shortcomings that do not allow to fully ensure the required level of reliability of equipment.

The relevance of the study is due to the fact that the existing system of AWME maintenance according to the authors, is obsolete and has shortcomings that lead to excessive expenditure of human and material resources and significant underutilization of battery resources. Establishing the optimal frequency of battery maintenance will reduce the complexity of current repairs, the number of operations and downtime AWME in general.

More progressive can be considered a maintenance system, which includes elements of maintenance by condition ("with parameter control" or "with control of the level of reliability") and elements of the planned and preventive maintenance system by operation (by resource). Such a "mixed" battery maintenance can be implemented as part of long-term planning of battery care and battery management in the army.

In this regard, there is a need to obtain prompt and reliable information about the current state of the battery to determine its timely replacement.

Analysis of recent research and publications of recent research and publications on the above issues shows that the known methods of battery rapid assessment are based on the characteristics obtained by indirect measurements. The basis of such methods are special devices - GB analyzers (trackers). The principle of their operation is based on measuring the battery's parameters of the (usually internal resistance) on alternating current for $10-20$ seconds. 
The values of the measured parameters allow to estimate the degree of the battery degradation and to predict the value of the reserve and nominal capacity, the current of the starter discharge of the battery.

Known today methods of battery's technical state monitoring are characterized by long duration, the negative impact of deep discharge, as well as significant energy and human costs [1-3].

Express-diagnosis allows to reduce these shortcomings to a minimum and is based on the mathematical description of a battery means of parameters, proceeding from their properties $[4,5]$.

The goal of the study is the development of a methodology for assessing the lead-acid batteries' parameters and to provide recommendations for their long-term management and carrier in the army.

This goal defined the following research tasks:

- on the basis of the lead-acid batteries operation experience to define a set of diagnostic parameters on which it is possible to draw a conclusion about the technical state of a battery and change of its electric, operational and design properties;

- to determine the correlations between the properties of the battery and make their assessment based on the established criteria;

- to build a diagnostic graph-model of a battery in the form of a correlation galaxy;

- to justify the lead-acid batteries carrier and management minimum diagnosis which can be carried out during their life cycle management ra status control under the lack of time.

General scientific and special methods of scientific knowledge are used.

\section{Main material}

1. Determining the set of diagnostic parameters to assess the battery technical state and change its electrical characteristics.

Analysis of the technical literature [4, 6] allowed us to identify parameters by which we can assess the battery technical state.

Conventionally, they can be divided into structural, electrical and operational.

To further formalize the problem of determining the correlations between the battery's parameters, each of the parameters corresponds to the symbol. Summary data are presented in tables 1,2 and 3 .

Note that the term "available capacity" is defined as the capacity that the battery has in the current conditions. The actual capacity is determined on a fully charged battery at a constant temperature $T=25 \pm 2{ }^{\circ} \mathrm{C}$. Under such conditions, the ratio $C=F C C$. In other conditions, the actual capacity will be the calculated value of $k C$, , $k$ is a coefficient takes into account the change in the capacity of the battery depending on the temperature [6-9].

According to the world experience of battery operation, the assessment of their technical state is similar to the Battery Management and Battery Status Control procedures, so the authors have invited to introduce such generalized parameters that characterize the technical state of battery operated in the military.
Table 1 - List of the main design battery's parameters to determine the technical condition

\begin{tabular}{|l|l|c|c|c|}
\hline No & \multicolumn{1}{|c|}{ Name } & Unit & $\begin{array}{c}\text { Sym- } \\
\text { bol }\end{array}$ & $\begin{array}{c}\text { Nota } \\
- \text { tion }\end{array}$ \\
\hline 1 & Overall dimensions of plates & $\mathrm{m}^{3}$ & $\mathrm{D}$ & $x_{1}$ \\
\hline 2 & $\begin{array}{l}\text { Weight of plates (with active } \\
\text { Substance) }\end{array}$ & $\mathrm{kg}$ & $\mathrm{m}_{\mathrm{pl}}$ & $x_{2}$ \\
\hline 3 & Porosity of plates & $\%$ & $\gamma$ & $x_{3}$ \\
\hline 4 & Chemical composition of plates & - & $\lambda$ & $x_{4}$ \\
\hline 5 & Separator type & - & - & $x_{5}$ \\
\hline 6 & Battery connection method & - & - & $x_{6}$ \\
\hline 7 & Number of batteries & $\mathrm{piece}$ & - & $x_{7}$ \\
\hline 8 & Active mass utilization factor & $\%$ & $\mathrm{~N}_{\mathrm{ac}}$ & $x_{8}$ \\
\hline
\end{tabular}

Table 2 - List of the main operating parameters of the battery to determine the technical condition

\begin{tabular}{|l|l|c|c|c|}
\hline No & \multicolumn{1}{|c|}{ Name } & Unit & $\begin{array}{c}\text { Sym- } \\
\text { bol }\end{array}$ & $\begin{array}{c}\text { Nota } \\
- \text { tion }\end{array}$ \\
\hline 1 & Electrolyte volume & 1 & $V_{e л}$ & $x_{9}$ \\
\hline 2 & Electrolyte density & $\mathrm{g} / \mathrm{sm}^{3}$ & $\rho$ & $x_{10}$ \\
\hline 3 & Starting current & $\mathrm{A}$ & $C C A$ & $x_{11}$ \\
\hline 4 & Discharge time & hour & $t_{d}$ & $x_{12}$ \\
\hline 5 & Charge time & hour & $t_{c}$ & $x_{13}$ \\
\hline 6 & Self-discharge & $\mathrm{A}$ & $C$ & $x_{14}$ \\
\hline 7 & Service life & cycle & $n$ & $x_{15}$ \\
\hline 8 & Service life & piк & $l$ & $x_{16}$ \\
\hline 9 & Number of faulty batteries & piece & $N_{B}$ & $x_{17}$ \\
\hline 10 & Condition of leads & - & - & $x_{18}$ \\
\hline 11 & Condition of the body & - & - & $x_{19}$ \\
\hline 12 & Condition of the plug & - & - & $x_{20}$ \\
\hline 13 & Condition of cover & - & - & $x_{21}$ \\
\hline 14 & Temperature & ${ }^{\circ} \mathrm{C}$ & $T$ & $x_{22}$ \\
\hline
\end{tabular}

Table 3 - List of basic electrical parameters of the battery to determine the technical condition

\begin{tabular}{|l|l|c|c|c|}
\hline No & \multicolumn{1}{|c|}{ Name } & Unit & $\begin{array}{c}\text { Sym- } \\
\text { bol }\end{array}$ & $\begin{array}{c}\text { Nota } \\
- \text { tion }\end{array}$ \\
\hline 1 & Internal Resistance & Ohm & $R$ & $x_{23}$ \\
\hline 2 & Design Capacity: & $\mathrm{A} \cdot \mathrm{h}$ & $D C$ & $x_{23}$ \\
\hline 3 & Full-Charge Capacity & $\mathrm{A} \cdot \mathrm{h}$ & $F C C$ & $x_{24}$ \\
\hline 4 & Available Capacity & $\mathrm{A} \cdot \mathrm{h}$ & $\mathrm{C}$ & $x_{25}$ \\
\hline 5 & Voltage & $\mathrm{V}$ & $\mathrm{U}$ & $x_{26}$ \\
\hline 6 & Open-Circuit Voltage & $\mathrm{V}$ & $\mathrm{OCV}$ & $x_{27}$ \\
\hline 7 & Terminate Voltage & $\mathrm{B}$ & $\mathrm{TU}$ & $x_{28}$ \\
\hline 8 & Discharge Current & $\mathrm{A}$ & $\mathrm{I}_{\mathrm{d}}$ & $x_{29}$ \\
\hline 9 & Charge Current & $\mathrm{A}$ & $\mathrm{I}_{\mathrm{ch}}$ & $x_{30}$ \\
\hline
\end{tabular}

$\mathrm{SoH}$ (State of Health) is defined as the degree of performance of the battery, which reflects the current state of the battery compared to ideal. In accordance with the parameter $\mathrm{SoH}$ set the notation $x_{31}$.

SoC (State of Charge) is defined as the degree of charge of the battery, which shows how much of the full charge is still accumulated in the battery. In accordance with the parameter $S o C$ we set the symbol $x_{32}$.

The $S o C$ will determine how much battery power is left to maintain and charge, while the $\mathrm{SoH}$ will indicate when the battery needs to be replaced $[4,7,8]$. Thus, the technical condition of the battery will be determined by the parameter vector

$$
\bar{X}=\left(x_{1}, x_{2}, \ldots, x_{n}\right)^{T}, i=\overline{1, n},
$$

here $n$ is number of parameters that determine the technical condition of the GB. 
2. Statistical data processing using the mathematical apparatus of correlation analysis.

Rechargeable batteries can operate within the specified service life in compliance with the rules of operation and storage. As noted, the greatest impact on the performance and service life of batteries are operating conditions, such as ambient temperature, depth of discharge, discharge and charging currents, and so on. Note that based on the results of the study, we can conclude that the increase in internal resistance reduces the power characteristics of the battery, but to a greater extent there is a degradation of capacity. At the same time, the battery maintains a normal value of the starting current almost until the very end of the service, and their capacity is constantly reduced. Fig. 1 shows the ratio of capacitance and starting current 20 of the studied $12 \mathrm{ST}-85 \mathrm{R}$ batteries depending on the power.

The main reason for the failure of the battery can be considered to be the loss of battery capacity, as illustrated in Fig. 2. The values of the capacitance are marked on the abscissa axis, and the values of the starting current are marked on the ordinate axis.

As one can see from the figure, most batteries have maintained the allowable values of the starting current when the capacity drops below $40 \%$.

For further research, an assumption was made about the normal nature of the distribution of the batteries' parameters to assess its technical state. The study was based on information and analytical materials on the impact of operating conditions on performance and service life of batteries.
In order to define the relationship between the parameters that determine the technical condition of the battery and to make their assessment, it is proposed to use a mathematical apparatus of correlation analysis, namely multiple correlation. The results of monitoring $n$ batteries can be presented as a matrix.

The results of monitoring $n$ batteries can be presented as a matrix

$$
X=\left[\begin{array}{cccccc}
x_{11} & x_{12} & \ldots & x_{1 j} & \ldots & x_{1 k} \\
x_{21} & x_{22} & \ldots & x_{2 j} & \ldots & x_{2 k} \\
\ldots & \ldots & \ldots & \ldots & \ldots & \ldots \\
x_{i 1} & x_{i 2} & \ldots & x_{i j} & \ldots & x_{i k} \\
\ldots & \ldots & \ldots & \ldots & \ldots & \ldots \\
x_{n 1} & x_{n 2} & \ldots & x_{n j} & \ldots & x_{n k}
\end{array}\right],
$$

where the values of the type "Battery - parameter" characterize the state of the $i$-th battery on the $j$-th parameter.

We assume that, $\bar{X}_{1}, \ldots, \bar{X}_{n} \ldots$, form a general population with a distribution density:

$$
\begin{gathered}
f_{\bar{X}}\left(x_{1}, x_{2}, \ldots, x_{k}\right)= \\
=\frac{1}{\sqrt{(2 \pi)^{k}|\Sigma|}} \exp \left(-\frac{1}{2}(x-\bar{\mu})^{T} \Sigma^{-1}(x-\bar{\mu})\right),
\end{gathered}
$$

here $|\Sigma|$ is the determinant of the covariance matrix of dimension $k \times k ; \mu$ is the $k$-dimensional vector of mathematical expectations.

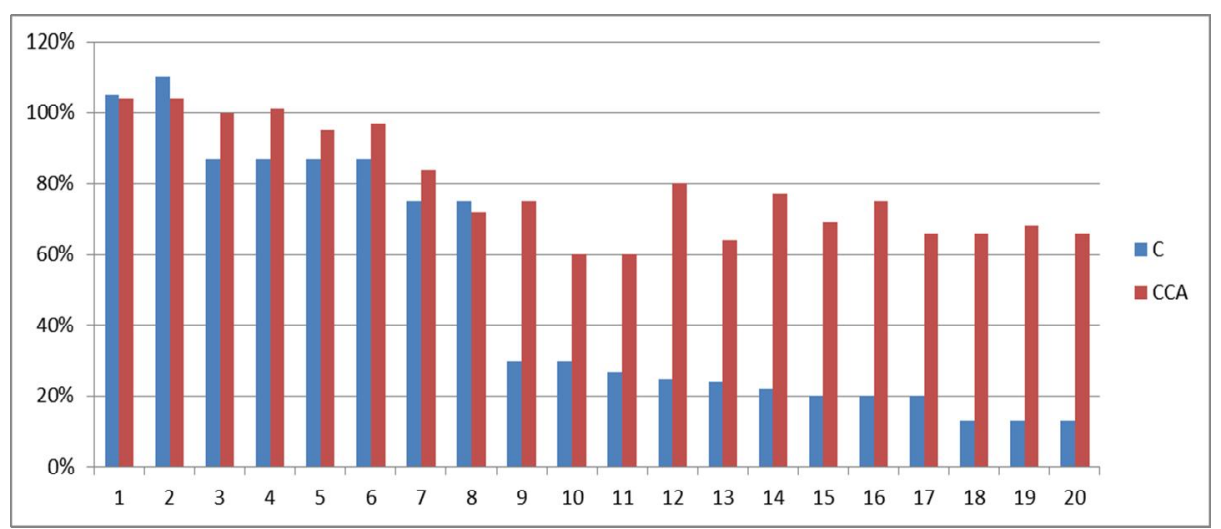

Fig. 1. The ratio of capacitance and starting current of the 20 studied batteries depending on the power

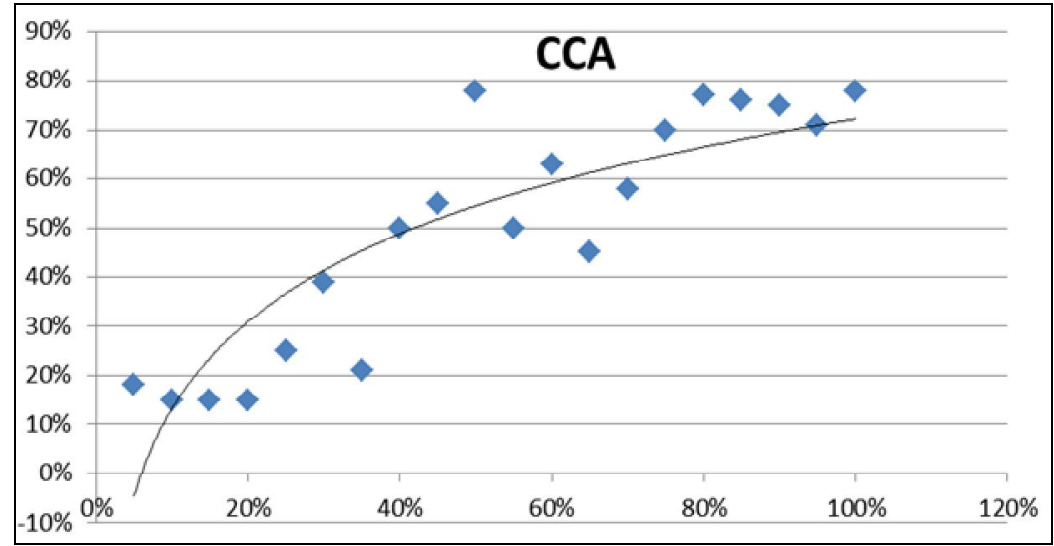

Fig. 2. Indicators of capacity and starting current of 20 age batteries 
Using the well-known apparatus of mathematical statistics and probability theories, it is proposed to estimate the numerical characteristics of the vector of parameters $\bar{X}=\left(x_{1}, x_{2}, \ldots, x_{n}\right)^{T}$, partial and multiple correlation coefficients $[10,11]$.

The authors performed statistical processing of the results of observations of $n=20$ batteries at different terms of their operation for $k=31$ parameters.

Data sampling can be considered representative and sufficient for statistical processing. Using the Statistica application package, the numerical values of the matrix $X$ were estimated and, based on the assumption of the normal nature of the distribution of a certain $k$-dimensional general population, partial and multiple correlation coefficients were obtained.

Fig. 3 shows a fragment of the dialog box during operation of the application package Statistica [12].

To perform calculations, the threshold level of significance of the null hypothesis about the value of even correlation coefficients was set $\alpha=0,05$.

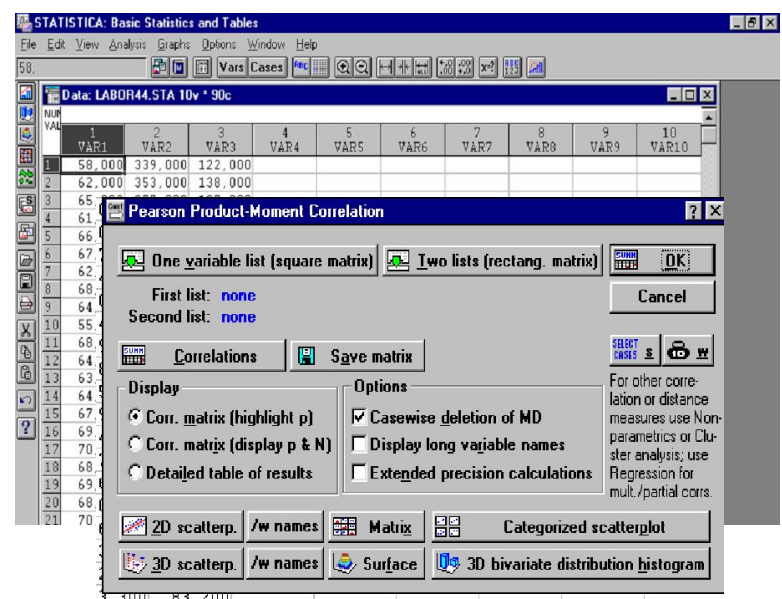

Fig. 3. Carrying out calculations in the Statistica application package
As a result, the number of parameters for assessment the battery technical state was reduced to $m=10$ :

$y_{1}$ - electrolyte density $\rho$;

$\mathrm{y}_{2}-$ internal resistance $R$;

$\mathrm{y}_{3}-$ design capacity $D C$;

$\mathrm{y}_{4}$ - temperature $T$;

$\mathrm{y}_{5}$ - full-charge capacity $F C C$;

$\mathrm{y}_{6}$ - discharge time $t_{d}$;

$\mathrm{y}_{7}-\mathrm{SoC}$;

$\mathrm{y}_{8}-$ discharge current $I_{d}$;

$\mathrm{y}_{9}-\mathrm{SoH}$

$\mathrm{y}_{10}$ - open-circuit voltage $O C V$.

The results of correlation and factor analysis showed that the effects of four electrical, four operational and two generalized battery parameters are well correlated.

Thus, the relationship between the battery parameters assesses its technical state, is illustrated by a correlation matrix of the form:

$$
K=\left\|\begin{array}{cccc}
K_{11} & K_{12} & \ldots & K_{1 m} \\
& K_{22} & \ldots & K_{2 m} \\
& & \ldots & \ldots \\
& & & K_{m m}
\end{array}\right\| .
$$

In order to clarify the statements about the correlations of the elements of the battery's parameters vector $\bar{Y}=\left(y_{1}, y_{2}, \ldots, y_{m}\right)^{T}$ let's use a normalized correlation matrix

$$
\left\|r_{i j}\right\|=\left\|\begin{array}{ccccc}
1 & r_{12} & r_{13} & \ldots & r_{1 m} \\
& 1 & r_{23} & \ldots & r_{2 m} \\
& & 1 & \ldots & r_{3 n} \\
& & & 1 & \ldots \\
& & & & 1
\end{array}\right\| .
$$

According to the results of the calculations, the following values of the matrix (4) were obtained:

$$
\left\|r_{i j}\right\|=\| \begin{array}{cccc}
1 & 0,62 & 0,12 & 0,1 \\
& 1 & -0,39 & -0,2 \\
& & 1 & 0,04 \\
& & & 1 \\
& & & \\
& & &
\end{array}
$$

As an example, the results indicate a low correlation between the discharge current and the capacitance of the battery, namely $r_{7,8}=0,55$. The authors note the possibility of establishing causal relationships between the battery's parameters.

For example, the internal resistance is influenced by other parameters, such as electrolyte density (positive correlation), and the full-charge capacity FCC depends on the internal resistance (negative correlation). It is proposed

$$
\begin{array}{cccccc}
0,49 & 0,38 & 0,46 & 0,38 & 0,48 & 0,29 \\
-0,33 & -0,78 & -0,4 & -0,78 & -0,49 & -0,44 \\
0,45 & 0,1 & 0,13 & 0,1 & 0,73 & 0,2 \\
0,61 & 0,49 & 0,43 & 0,49 & 0,36 & 0,39 \\
1 & 0,5 & 0,59 & 0,5 & 0,59 & 0,66 \\
& 1 & -0,42 & -0,8 & -0,43 & -0,33 \\
& & 1 & 0,46 & 0,4 & 0,53 \\
& & & 1 & 0,45 & 0,43 \\
& & & & 1 & 0,29 \\
& & & & & 1
\end{array}
$$

to use the identified dependences to build a diagnostic graph model of the lead-acid battery.

3. Diagnostic graph-model of GB in the form of a correlation galaxy.

The presentation of generalized results in the form of a correlation galaxy makes it possible to build a diagnostic graph-model of battery in the form of a correlation galaxy. The vertices of the graph will be the battery's parameters, and the arcs will indicate the 
relationship of the parameters. Arcs from the cause to the effect are drawn between the interconnected vertices, which in this case will take into account the correlation sign.

Fig. 4 shows a fragment of the graph model of the lead-acid battery. The vertices of the graph corresponding to the operating parameters of the battery (electrolyte density, temperature, time and discharge current) are marked in green.
The vertices of the graph corresponding to the battery's electrical parameters (internal resistance, design capacity, full-charge capacity and discharge current) are marked in orange, and $\mathrm{SoH}$ and $\mathrm{SoC}$ are marked in pink.

Parameters the correlation between which more than 0,5 is proposed to be used for the battery minimum diagnosis in the course of their life cycle, taking into account the existing lack of time.

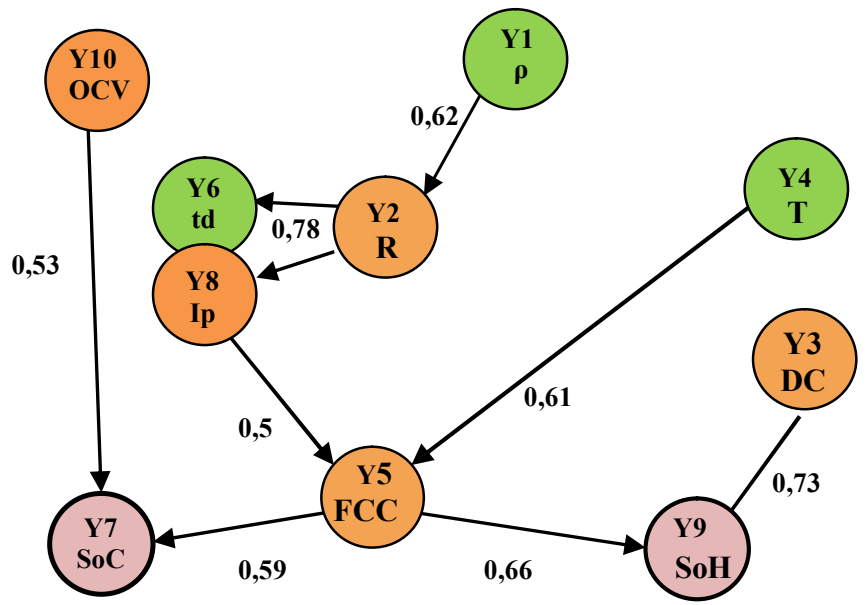

Fig. 4. Fragment of the diagnostic graph-model of GB in the form of a correlation galaxy

In the process of discharge or discharge $A B$ is "pass" of capacity. Given the close correlation between the parameters $y_{6}$ - discharge time $t_{d}$ and $y_{8}$ - discharge current $I_{d}$, it is proposed to introduce the concept of passed charge $C_{\text {pass }}$, i.e. the capacity given or received by the battery during discharge / charge, respectively.

$$
C_{\text {pass }}=I_{d} \cdot t_{d}
$$

Practical calculation of $C_{\text {pass }}$, can be performed by an integrated Coulomb counter during battery charge or dischargei or by direct measurement of current and time.

4. Battery minimum diagnosis for dynamic monitoring of its technical state during the life cycle.

It should be noted that battery diagnosing in the process of their life cycle will allow to effectively calculate the time of replacement and to carry out longterm planning of their maintenance.

Of course, the effectiveness of such measures will increase significantly with the use of modern information technology, electronic measuring devices, development of dynamic interfaces, creation of interactive databases, etc. First of all, it should be noted that some measurements are indirect to determine the $\mathrm{SoC}$ and $\mathrm{SoH}$ of the battery.

Therefore, to implement the GB diagnostic model, for example, to develop a dynamic interface for longterm maintenance planning, we will determine the amount of the battery minimum diagnosis to monitor its $\mathrm{SoC}$ and $\mathrm{SoH}$.

On the analysis of the correlation analysis results, the set of the minimum diagnostic parameters to assess the battery technical state is based on the possibility of their dynamic monitoring and analytical calculations. Namely, the 12ST-85R battery minimum diagnosis will be to monitor its Open-circuit voltage, temperature and passed charge capacity.

According to the authors, a promising direction in the development of battery operation can be considered the development of Battery Tracks - software and hardware devices for Battery care and battery management [9].

By monitoring $\mathrm{SoC}$ and $\mathrm{SoH}$ of the lead-acid battery using such a device, it is possible to provide a better user experience by continuously and accurately reporting the remaining charge, and also by cautioning when a battery needs to be replaced.

In the future, the authors plan to explore the possibility of monitoring such important battery's parameters impedance, depth of discharge, residual capacity, etc.

\section{Conclusions}

1. Analysis of the experience of the lead-acid batteries operation determines a set of diagnostic parameters, which can be used to draw a conclusion about the technical state of a battery and change of its electric, operational and design properties.

As generalized diagnostic parameters of the battery technical state can be considered the State of Health and the state of charge $\mathrm{SoC}$.

2. Statistical data processing using the mathematical apparatus of correlation analysis allows to determine the causal and dependencies between the battery's parameters and make their assessment based on the established criteria. 
3. Presentation of generalized results in the form of a correlation galaxy makes it possible to build a diagnostic graph-model of causal relationships of battery's parameters in the form of a correlation galaxy.

4. Control of the $\mathrm{SoC}$ and $\mathrm{SoH}$ of the lead-acid battery will ensure the monitoring of the remaining charge, as well as the issuance of a warning about the need to replace the battery.

A promising direction in the development of battery operation can be considered the development of battery-powered trackers - software and hardware devices capable of caring for battery care and battery management.

\section{REFERENCES}

1. Gumelev, V.Yu. and Kochurov, A.A. (2013), "Factors Affecting Battery Life", Issledovaniya v oblasti yestestvennykh nauk, No. 5, available at: http://science.snauka.ru/2013/05/4946.

2. Yurov, Yu.Yu., Postnikov, A.A. and Gumelev, V.Yu. (2015), "Brief evaluation of methods for diagnosing lead-acid storage batteries", Sovremennaya tekhnika i tekhnologii, No. 12, available at: http://technology.snauka.ru/2015/12/8775.

3. Kochurov, A.A., Shevchenko, N.P. and Gumelev, V. Yu. (2009), Teoreticheskiye osnovy resheniya problemy uvelicheniya srokov sluzhby akkumulyatornykh batarey pri khranenii i povysheniya effektivnosti sposobov ikh vosstanovleniya [Theoretical foundations for solving the problem of increasing the service life of storage batteries and improving the efficiency of methods for their recovery], RVAI, Ryazan, RU.

4. Patrick T., Moseley, Jurgen, Garche, C.D. Parker, and D.A.J. Rand (2004), Valve-Regulated Lead-Acid Batteries, Elsevier B. V., NL, Amsterdam.

5. Aleshkin, A.A. (2013), "Method of on-line diagnostics of the available capacity of lead-acid accumulators (batteries)", Elektrokhimicheskaya energetika, No. 1, pp. 46-53.

6. Postnikov, A.A., Yurov, Yu.Yu. and Gumelev, V.Yu. (2018), "Evaluation and selection of parameters for monitoring the technical condition of batteries", Nauchnyy rezerv, No. 1(1), pp. 54-59.

7. (2020), Battery Council International, Lead Acid Batteries, available at: http://batterycouncil.org/?page=Lead_Acid_Batteries.

8. (2020), Battery University, How to Measure State-of-Charge, available at: http://batteryuniversity.com/learn/article/how to measure state of charge.

9. Simon, Wen (2006), Impedance TrackTM Gas Gauge for Novice, Application Report (SLUA375), Texas Instruments, available at: http://www.ti.com/lit/an/slua375/slua375.pdf.

10. Grzhibovsky, A.M. (2008), "Correlation analysis", Ekologiya cheloveka, No. 9, available at: https://cyberleninka.ru/article/n/korrelyatsionnyy-analiz.

11. (2020), Lead-acid batteries: The growing need for monitoring state-of-charge and health, Cambridge, MA, URL: https://www.electronicproducts.com/lead-acid-batteries-the-growing-need-for-monitoring-state-of-charge-and-health/

12. Borovikov, V.P. and Borovikov, I.P. (1998), STATISTICA - Statistical analysis and data processing in the Windows environment, "Filin", Moscow, RU.

Received (Надійшла) 11.11.2020

Accepted for publication (Прийнята до друку) 27.01.2021

ВідОмості ПРо АВтоРів / АвоUT THE AUTHORS

Макогон Олена Анатоліївна - кандидат технічних наук, доцент кафедри бронетанкового озброєння та військової техніки, Військовий інститут танкових військ Національного технічного університету “ХПІ”, Харків, Україна;

Helen Makogon - Candidate of Technical Sciences, Associate Professor of the Armored vehicles and military equipment Department, Military Institute of Tank Troops of National Technical University "KhPI”, Kharkiv, Ukraine; e-mail: helmkg@ukr.net; ORCID: https://orcid.org/0000-0003-1112-8707.

Сучко Роман Ігоревич - магістрант за профілем кафедри бронетанкового озброєння та військової техніки, Військовий інститут танкових військ Національного технічного університету “ХПІ”, Харків, Україна;

Roman Suchko - Undergraduate Cadet of the Armored weapons and military equipment Department, Military Institute of Tank Troops of National Technical University "Kharkiv Polytechnic Institute", Kharkiv, Ukraine; e-mail: romansuchko@gmail.com; ORCID: https://orcid.org/0000-0003-4116-7336.

Москаленко Віктор Іванович - доцент кафедри бронетанкового озброєння та військової техніки, Військовий інститут танкових військ Національного технічного університету “ХПI”, Харків, Україна;

Viktor Moskalenko - Associate Professor of the Armored vehicles and military equipment Department, Military Institute of Tank Troops of National Technical University "Kharkiv Polytechnic Institute", Kharkiv, Ukraine; e-mail: kaf ing fvp@ukr.net; ORCID: https://orcid.org/0000-0002-4183-7953.

Калінін Ігор Вікторович - викладач кафедри бронетанкового озброєння та військової техніки, Військовий інститут танкових військ Національного технічного університету “Харківський політехнічний інститут”, Харків, Україна; Igor Kalinin - Lecturer of the Armored weapons and military equipment Department, Military Institute of Tank Troops of National Technical University "Kharkiv Polytechnic Institute", Kharkiv, Ukraine; e-mail: kalina7164@ukr.net; ORCID: https://orcid.org/0000-0002-3912-8285.

Бурдін Сергій Вікторович - вчитель фізики, Державна гімназія-інтернат 3 посиленою військово-фізичною підготовкою “Кадетський корпус", Харків, Україна;

Sergiy Burdin - Physics teacher, State boarding school with enhanced military and physical training "Cadet Corps", Kharkiv, Ukraine;

e-mail: fisservik@ukr.net; ORCID: https://orcid.org/0000-0002-9946-7545.

Іксариця Вікторія Вікторівна - вчитель вищої категорії, Державна гімназія-інтернат з посиленою військово-фізичною підготовкою "Кадетський корпус", Харків, Україна; 
Viktoriia Iksarytsia - teacher of the highest category, State boarding school with enhanced military and physical training "Cadet Corps", Kharkiv, Ukraine;

e-mail: vik05.69@ukr.net; ORCID: http://orcid.org/0000-0001-7288-0885.

Застосування математичного апарату кореляційного аналізу для визначення обсягу мінімального діагностування при динамічному моніторингу технічного стану свинцево-кислотних акумуляторних батарей

О. А. Макогон, Р. І. Сучко, В. І. Москаленко, І. В. Калінін, С. В. Бурдін, В. В. Іксариця

Анотація. Предметом вивчення в статті є оцінка термінів служби та планування технічного обслуговування при експлуатації свинцево-кислотних акумуляторних батарей (АБ). Метою дослідження є розробка методики оцінки параметрів АБ та термінів їх служби для надання рекомендації по довгостроковому плануванню технічного обслуговування та заміни батарей при експлуатації у військах. Завдання дослідження: на основі досвіду експлуатації АБ визначити множину діагностичних параметрів, за якими можна зробити висновок про технічний стан АБ та зміну ії електричних, експлуатаційних та конструкційних характеристик; визначити кореляційні залежності між параметрами АБ і зробити їх оцінку, виходячи з встановлених критеріїв; побудувати діагностичну граф-модель АБ у вигляді кореляційної плеяди; обгрунтувати мінімальне діагностування АБ, що може проводиться в процесі їх життєвого циклу 3 урахуванням наявного дефіциту часу. Методологічною основою дослідження стали загальнонаукові та спеціальні методи наукового пізнання. Отримані наступні результати: Визначено набір діагностичних параметрів для оцінки технічного стану акумуляторної батареї. Проведена статистична обробка даних з використанням математичного апарату кореляційного аналізу. Побудована діагностична граф-модель свинцево-кислотного акумулятора у вигляді кореляційної плеяди. Визначено обсяг мінімального діагностування батареї для оцінки технічного стану та терміну свинцевокислотних акумуляторів протягом їх життєвого циклу. Висновки. Аналіз досвіду експлуатації АБ визначає множину діагностичних параметрів, за якими можна зробити висновок про технічний стан батареї та зміну їі електричних, експлуатаційних та конструкційних характеристик. Узагальненими діагностичними параметрами технічного стану АБ можна вважати ступінь “здоров'я” акумулятора $\mathrm{SoH}$ та ступінь зарядженості SoC. Статистична обробка даних 3 використанням математичного апарату кореляційного аналізу дозволяє визначити причинно-наслідкові залежності між параметрами АБ і зробити їх оцінку, виходячи з встановлених критеріїв. Подання узагальнених результатів у вигляді кореляційної плеяди дає можливість побудувати діагностичну граф-модель АБ у вигляді кореляційної плеяди. Контроль $S o C$ та $S o H$ свинцево-кислотної батареї забезпечить моніторинг залишку заряду, а також видачу попередження про необхідність заміни батареї. Перспективним напрямом у розвитку експлуатації АБ можна вважати розробку акумуляторних треккерів -апаратних приладів, здатних аналізувати динаміку змін їх електричних характеристик та оцінку терміну служби.

Кл юч ов і слов а: свинцево-кислотний акумулятор; догляд за акумуляторами; оцінка термінів служби; технічне обслуговування; експлуатація.

Применение математического аппарата корреляционного анализа для определения объема минимального диагностирования при динамичном мониторинге технического состояния свинцово-кислотных аккумуляторных батарей Е. А. Макогон, Р. И. Сучко, В. И. Москаленко, И. В. Калинин, С. В. Бурдин, В. В. Иксарица

Аннотация. Предметом изучения в статье является оценка сроков службы и планирование технического обслуживания при эксплуатации свинцово-кислотных аккумуляторных батарей (АБ). Целью исследования является разработка методики оценки параметров АБ и сроков их службы для выработки рекомендаций по долгосрочному планированию технического обслуживания и замены батарей при эксплуатации в войсках. Задачи исследования: на основе опыта эксплуатации АБ определить множество диагностических параметров, по которым можно сделать вывод о техническом состоянии АБ и изменение ее электрических, эксплуатационных и конструкционных характеристик; определить корреляционные зависимости между параметрами АБ и сделать их оценку, исходя из установленных критериев; построить диагностическую граф-модель АБ в виде корреляционной плеяды; обосновать объем минимального диагностирования АБ, которое может проводиться в процессе их жизненного цикла с учетом имеющегося дефицита времени. Методологічною основою дослідження стали загальнонаукові та спеціальні методи наукового пізнання. Получены следующие результаты. Определен набор диагностических параметров для оценки технического состояния аккумуляторной батареи. Произведена статистическая обработка данных с использованием математического аппарата корреляционного анализа. Построена диагностическая граф- модель свинцово-кислотного аккумулятора в виде корреляционной плеяды. Определен объем минимального диагностирования батареи для оценки технического состояния и срока свинцово-кислотных аккумуляторов в течение их жизненного цикла. Выводы. Анализ опыта эксплуатации АБ определяет множество диагностических параметров, по которым можно сделать вывод о техническом состоянии батареи и изменении ее электрических, эксплуатационных и конструкционных характеристик. Обобщенными диагностическими параметрами технического состояния АБ можно считать степень "здоровья" аккумулятора $\mathrm{SoH}$ и степень заряженности $S o C$. Статистическая обработка данных с использованием математического аппарата корреляционного анализа позволяет определить причинно-следственные зависимости между параметрами АБ и сделать их оценку, исходя из установленных критериев. Представление обобщенных результатов в виде корреляционной плеяды дает возможность построить диагностическую граф-модель АБ в виде корреляционной плеяды. Контроль $\mathrm{SoC} u \mathrm{SoH}$ свинцово-кислотной батареи обеспечит мониторинг уровня заряда, а также выдачу предупреждения о необходимости замены батареи. Перспективным направлением в развитии эксплуатации АБ можно считать разработку аккумуляторных треккеров - программно-аппаратных устройств, способных анализировать динамику изменений их электрических характеристик и оценку сроков службы.

Ключевые слова: свинцово-кислотный аккумулятор; уход за аккумуляторами; оценка сроков службы; техническое обслуживание; эксплуатация. 